\title{
Litter accumulation and its effect on seedling recruitment in a Southeast Brazilian Tropical Forest
}

\author{
SANDY LIA DOS SANTOS ${ }^{1}$ and IVANY F.M. VÁLIO ${ }^{1,2}$
}

(received: November 29, 2000; accepted: January 16, 2002)

\begin{abstract}
Litter accumulation and its effect on seedling recruitment in a Southeast Brazilian tropical forest). Litter directly and indirectly affects germination and development of seedlings through physical and chemical effects, being an important factor in the determination of plant community. The monthly accumulation of litter was studied from November 1996 to September 1998 and its relation to climatic factors (such as rainfall, photoperiod and temperature). Also the litter effect on the recruit-

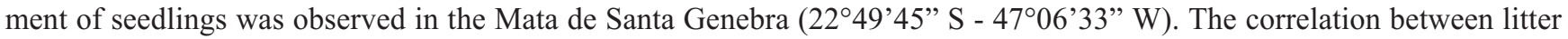
accumulation and climatic factors was very weak. Under the canopy, the removal of the litter layer increased seedling emergence. Seedling mortality was very high, even in the rainy season. This can be due possibly by the low light intensity under the canopy.

RESUMO - (Acúmulo de serrapilheira e seu efeito no recrutamento de plântulas em uma floresta tropical do sudeste brasileiro). A serrapilheira afeta direta e indiretamente a germinação e o desenvolvimento de plântulas através de efeitos físicos e químicos, sendo um fator importante na determinação de uma comunidade vegetal. Foram estudados o acúmulo mensal de serrapilheira durante o período de novembro de 1996 a setembro de 1998 e possíveis relações entre este e fatores climáticos (como precipitação pluviométrica, fotoperíodo e temperatura) e o papel da serrapilheira no recrutamento de plântulas na mata. $\mathrm{O}$ acúmulo mensal de serrapilheira apresentou fraca correlação com os fatores climáticos. Foi observado, no interior da mata, que a remoção da serrapilheira aumentou a emergência de plântulas; e a mortalidade destas foi muito alta mesmo no período chuvoso, podendo este fato ser devido à baixa intensidade luminosa no interior da mata.
\end{abstract}

Key words - litter accumulation, seedling recruitment, climatic factors, tropical forest

\section{Introduction}

The litter layer is composed of leaves, flowers, fruits, stems, plant debris and also in smaller proportion by animal residue covering the forest floor. The accumulation of litter depends on factors such as the community primary productivity as well as changes in the weather, with rainfall one of the main components (Vázquez-Yanes et al. 1990, Facelli \& Pickett 1991).

The amount of the litter accumulated at a site can be altered by the influx of litter from other sites or by efflux to other sites. This happens by the action of winds, floods, soil unevenness, etc. The microenvironment near to the litter may or may not favour its decay changing its accumulation (Xiong \& Nilsson 1997).

Litter can affect physically the emergence of seedlings as well as hindering their roots, from reaching the soil. Also, litter reduces soil temperature amplitude and water evaporation, increasing local humidity. On the contrary, sometimes litter reduces water infiltration from the rain to the soil. In gaps litter also acts as a light filter

1. Universidade Estadual de Campinas, Instituto de Biologia, Departamento de Fisiologia Vegetal, Caixa Postal 6109, 13083-970 Campinas, SP, Brasil.

2. Autor para correspondência: ivalio@bol.com.br affecting the germination of light-sensitive seeds (Eriksson 1995, Scariot 2000).

The decay of litter affects the chemical properties of the soil through release of phytotoxic substances which can inhibit root growth and subsequent seedling development or can increase the availability of nutrients in the soil, influencing seed germination and early growth of seedlings (Wardle et al. 1992). Seedling recruitment is the emergence of new seedlings in a particular site. Recruitment is strongly affected by the presence of the litter mainly in deciduous or semideciduous forests due to dependence of appropriate microhabitats for emergence and seedling survival (Eriksson 1995, Benitez-Malvido 1999, Kotorová \& Lëps 1999).

The objectives of this paper were to verify the relations between litter accumulation and climatic conditions (rainfall, photoperiod and temperature) as well as the role of the litter on the emergence of seedlings under natural conditions.

\section{Material and methods}

This study was carried on in the Mata de Santa Genebra ( $\left.22^{\circ} 49^{\prime} 45^{\prime \prime} \mathrm{S}-47^{\circ} 06^{\prime} 33^{\prime \prime} \mathrm{W}\right)$, near Campinas, SP. Characteristics of this forest, weather and soil are described in Morellato (1991) and Martins (1999).

To study accumulation of litter and seedling recruitment, 
40 sites of $1 \mathrm{~m}^{2}$ were demarcated under the canopy at least 10 $\mathrm{m}$ from the forest border and ca. $100 \mathrm{~m}$ apart. Twenty sites were demarcated in October 1996 (rainy season) and another 20 sites in May 1997 (dry season) next to the former ones.

Monthly the litter was scrapped off from each site and placed in polyethylene bags. These litter samples remained one week in the glasshouse to dry under air temperature and were subsequently weighed. This was done during 23 months (November 1996 to September 1998).

In the sites demarcated in May 1997 the litter was removed only to follow the emergence of the seedlings. From November 1996 to September 1997 the seedling recruitment was observed almost every 15 days. Afterward recruitment was followed monthly for one more year (until September 1998).

Data on rain precipitation and temperature were provided by the Meteorological Station of the University of Campinas, near the Mata de Santa Genebra. Photoperiod, for the latitude of $22^{\circ} \mathrm{S}$, was obtained from the table 171, Smithsonian Meteorological Tables, $6^{\text {th }}$ ed., 1951. Data are for the $15^{\text {th }}$ day of each month. All data on litter accumulation and climatic conditions were analysed by correlation analysis.

\section{Results and Discussion}

The total amount of litter collected in the 20, one square meter, sites between November 1996 to September 1998 was about $94 \mathrm{~kg} \cdot \mathrm{m}^{-2}$, equivalent to 25 ton.ha ${ }^{-1} \cdot$ year $^{-1}$. This result is higher than others found in the same region Morellato (1992); Durigan et al. (1996); Diniz \& Pagano (1997); Martins (1999), but very close to the ones predicted by Londsdale (1988) for tropical regions in altitudes between 300-1.000 m (22 to 26 ton.ha ${ }^{-1}$.year $\left.{ }^{-1}\right)$.

Discrepancies in these data can be due to different characteristics of different forests and different methods of litter sampling. For instance, in this study the litter samples were collected under canopy and weighed after being air-dried for one week, while Martins (1999) collected in gap sites and dried the litter at $80^{\circ} \mathrm{C}$ before weighing.

The spatial and temporal variation of litter accumulation in different sites was very high. For example in April 1998, at site 3 there was no litter accumulation while at site 8 the accumulation reached $0.5 \mathrm{~kg} . \mathrm{m}^{-2}$. Between years, site 3 where no litter accumulation was observed in April 1998, had 0.33 $\mathrm{kg} . \mathrm{m}^{-2}$, in April 1997. The monthly mean varied from $0.16 \pm 0.07$ to $0.37 \pm 0.17 \mathrm{~kg} \cdot \mathrm{m}^{-2}$ from November 1996 to October 1997 and $0.11 \pm 0.06$ to $0.33 \pm 0.12 \mathrm{~kg} \cdot \mathrm{m}^{-2}$ from November 1997 to September 1998. These variations were expected due to the heterogeneity of floristic composition of the forest, winds and soil topography (Facelli \& Pickett 1991, Cintra 1997).
Reduction in rainfall in February, March and April was followed by an increase in litter accumulation in 1997 but not in 1998 (figure 1). Similar to Swaine et al. (1990) in Ghana, Morellato (1992) in Serra do Japi in São Paulo and Haase \& Hirooka (1998) in Mato Grosso, increases in litter accumulation were observed in dry season, but in this study increases of litter were also observed in the rainy season.

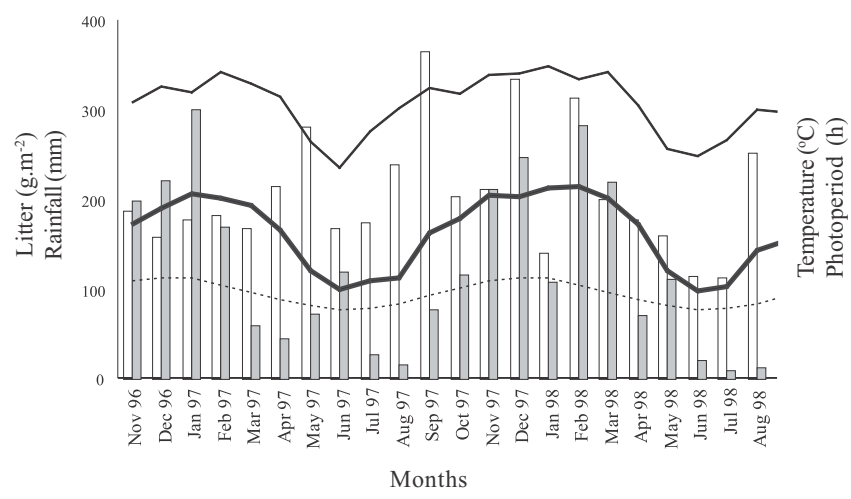

Figure 1. Litter accumulation $\left(\mathrm{g} \cdot \mathrm{m}^{-2}\right)$ in the sites of the Mata de Santa Genebra (Campinas, SP) and climatic factors rainfall ( $\mathrm{mm}$ ), photoperiod $(\mathrm{h})$ and temperature $\left({ }^{\circ} \mathrm{C}\right)$ from November 1996 to September 1998. $\square=$ Litter; $\square=$ Rainfall; $\_=$Maximum temperature; - = Minimum temperature and --$=$ Photoperiod.

There was no significant correlation between litter and climatic data of the same month or between litter and climatic data of preceding three months (Table 1). Similar results were obtained by Wright \& Cornejo (1990) in an irrigated area in Barro Colorado Island (Panama) where litter accumulation and flowering were not affected by increasing the soil water potential. On the contrary, Londsdale (1988) showed a positive correlation between litter and rainfall and evaporation.

Most litter is composed of leaves, and its accumulation is a consequence of interactions between biotic and abiotic factors. Leaf senescence and abscision

Table 1. Correlation between accumulation of litter collected in Mata de Santa Genebra, (Campinas, SP) and climatic factors in the same month and with one, two and three preceding months. $\mathrm{RF}=$ rainfall; $\mathrm{PH}=$ photoperiod; $\mathrm{Tmax}=\operatorname{maximum}$ temperature and $\mathrm{Tmin}=$ minimum temperature.

\begin{tabular}{lrrrr}
\hline & \multicolumn{4}{c}{ Coefficient of correlation } \\
& RF & PH & Tmax & Tmin \\
\hline Same month & 0.11 & 0.09 & 0.17 & 0.12 \\
One month before & 0.11 & 0.09 & 0.16 & 0.11 \\
Two month before & -0.16 & 0.02 & 0.13 & 0.03 \\
Three month before & -0.14 & -0.07 & -0.04 & -0.09 \\
\hline
\end{tabular}


are very complex biotic processes that makes their association with climatic factors even more difficult to understand (Facelli \& Pickett 1991). According to Morellato (1991), 33\% of 118 species, in the Mata de Santa Genebra abscised their leaves in the rainy season and $67 \%$ in the dry season. This means that leaf fall from deciduous and semideciduous species occurs almost all year around. Considering that the amount of leaf fall varies widely between species and between individuals of the same species, a correlation between litter and climatic factors is improbable.

Seedling recruitment had large spatial and temporal variability. At site 17 , on $9 / 28 / 1997$, no new seedlings were observed while on 10/12/1997 the emergence of 300 seedlings was registered at this site. On same day, no seedling emergence was recorded for site 11 .

These variations are possibly due to the efficient seed dispersal of some species, phenology and distribution of individuals in the forest as well as own physiology of seeds and seedlings (Morellato 1991, Grombone-Guaratini 1999). High seedling mortality was observed at all sites, mainly during the dry season due to dehydration and other physical factors such as soil buried and low radiance (all sample sites were located under the canopy). Biotic factors such as predators action and diseases may also cause seedling mortality (Veenendaal et al. 1995).

Data on variation of seedling emergence in the studied sites under the canopy associated with rainfall are presented in figures 2 and 3. Mortality occurred even in the rainy season; in the period between 11/29/1997

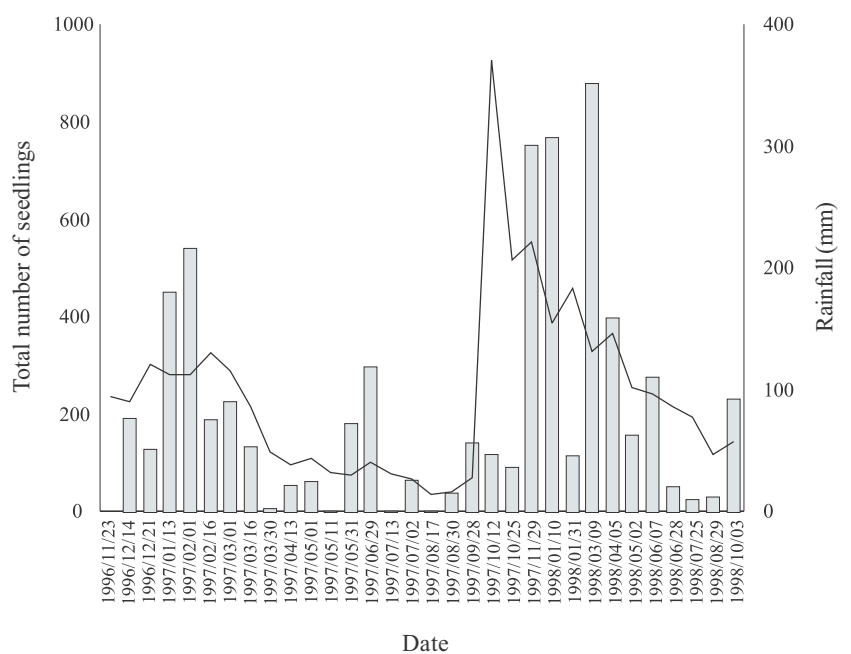

Figure 2. Rainfall and total number of seedlings recorded in the 20 sites demarcated from November 1996 to October 1998 in the Mata de Santa Genebra (Campinas, SP). - - = total number of seedlings; $\square=$ rainfall.

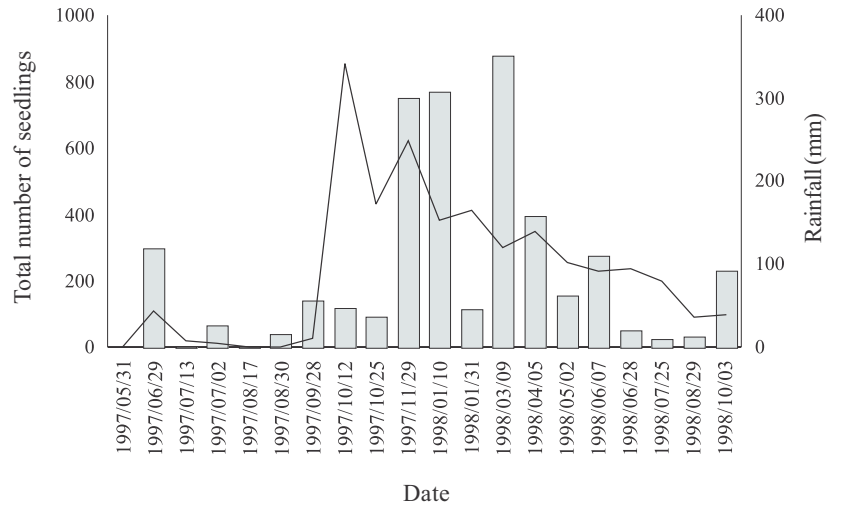

Figure 3. Rainfall and total number of seedlings recorded in the 20 sites demarcated from May 1997 to October 1998 in the Mata de Santa Genebra (Campinas, SP). - = total number of seedlings; $\square=$ rainfall .

and 1/10/1998 the number of seedlings was reduced in $70 \%$ without a reduction of rainfall. A high positive correlation between the seedling recruitment in the sites demarcated in October 1996 (rainy season) and May 1997 (dry season) was observed (98.7 \%).

It is possible that very small seedlings cannot stand even superficial soil dehydration, caused by a few days of drought. Mortality can also be due to very low radiance under the canopy, where small seed with low reserves cannot survive even without water stress (Swaine et al. 1990).

Removal of litter layer in the rainy season increased significantly seedling density (January 1997; $U=46.5$, $\mathrm{P}<0.05$, Mann-Whitney U-test) when compared to adjacent intact sites, suggesting an inhibitory effect on seedling recruitment in this season. In the dry season (April and July 1997) and beginning of the rainy season (September 1997) there were no significant differences between the means. In the 20 intact sites the total number of seedlings recorded was 63, 53, 21 and 25 in January, April, July and September of 1997, respectively and 282, 97, 68 and 69 in the same months in the sites without litter layer. These results are in agreement to several authors (Eriksson 1995).

Seedling recruitment also increased in response to rain, even a small increase in rainfall was enough to increase the number of seedling emergence. The patterns of recruitment from the rainy season and dry season were very similar. It is suggested that the peak of seedling emergence in 10/12/1997 (figure 2) is not due to the seed bank but from recently dispersed seeds (this is the time of seed dispersal of most species of the Mata de Santa Genebra) (Morellato 1991). 
Acknowledgements - We thank FAPESP (Fundação de Amparo à Pesquisa do Estado de São Paulo) for financial support (Process number 97/11647-0).

\section{References}

BENITEZ-MALVIDO, J. \& KOSSMANN-FERRAZ, I.D. 1999. Litter cover variability affects seedling performance and herbivory. Biotropica 31:598-606.

CINTRA, R. 1997. Leaf litter effects on seed and seedling predation of the palm Astrocaryum murumuru and the legume tree Dipteryx micrantha in Amazonian forest. Journal of Tropical Ecology 13:709-725.

DINIZ, S. \& PAGANO, S.N. 1997. Dinâmica de folhedo em floresta mesófila semidecídua no município de Araras, SP. I. Produção, decomposição e acúmulo. Revista do Instituto Florestal 9:27-36.

DURIGAN, G., LEITÃO FILHO, H.F. \& PAGANO, S.N. 1996. Produção de folhedo em matas ciliares na região oeste do Estado de SP. Revista do Instituto Florestal 8:187-199.

ERIKSSON, O. 1995. Seedlings recruitment in deciduous forest herbs: the effects of litter, soil chemistry and seed bank. Flora 190:65-70.

FACELLI, J.M. \& PICKETT, S.T.A. 1991. Plant litter: its dynamics and effects on plant community structure. Botanical Review 57:2-32.

GROMBONE-GUARATINI, M.T. 1999. Dinâmica de uma floresta estacional semidecidual: o banco, a chuva de sementes e o estrato de regeneração. Tese de doutorado, Universidade Estadual de Campinas, Campinas.

HAASE, R. \& HIROOKA, R.Y. 1998. Structure, composition and small litter dynamics of a semideciduous forest in Mato Grosso, Brazil. Flora 193:141-147.

KOTOROVÁ, I. \& LËPS, J. 1999. Comparative ecology of seedling recruitment in an oligotrophic wet meadow. Journal of Vegetation Science 10:175-186.

LONDSDALE, W.M. 1988. Predicting the amount of litterfall in forest in the world. Annals of Botany 61:319-324.
MARTINS, S.V. 1999. Aspectos da dinâmica de clareiras em uma floresta estacional semidecidual no município de Campinas, SP. Tese de doutorado, Universidade Estadual de Campinas, Campinas.

MORELLATO, L.P.C. 1991. Estudo da fenologia de árvores, arbustos e lianas de uma floresta semidecídua no Sudeste do Brasil. Tese de doutorado, Universidade Estadual de Campinas, Campinas.

MORELLATO, L.P.C. 1992. Nutrient cycling in two south-east Brazilian forests. I. Litterfall and litter standing crop. Journal of Tropical Ecology 8:205-215.

SCARIOT, A. 2000. Seedling mortality by litterfall in Amazonian Forest fragments. Biotropica 32:662-669.

SWAINE, M.D., LIEBERMAN, D. \& HALL, J.B. 1990. Structure and dynamics of a tropical dry forest in Ghana. Vegetatio 88:31-51.

VASQUEZ-YANES, C., OROZCO-SEGOVIA, A. RINCON, E., SANCHEZ-CORONADO, M.E., HUANTE, P., TOLEDO, J.R. \& BARRADAS, V.L. 1990. Light beneath the litter in a tropical forest: Effects on seed germination. Ecology 71:1952-1958.

VEENENDAAL, E.M., SWAINE, M.D., AGYEMAN, V.K., BLAY, D., ABEBRESE, I.K. \& MULLINS, C.E. 1995. Differences in plant and soil water relations in and around a forest gap in Weast Africa during the dry season may influence seedling establishment survival. Journal of Ecology 83:83-90.

WARDLE, D.A., NICHOLSON, K.S. \& AHMED, M. 1992. Comparison of osmotic and allelopathic effects of grass leaf extracts on grass seed germination and radicle elongation. Plant Soil 140:315-319.

WRIGHT, S.J. \& CORNEJO, F.H. 1990. Seasonal drought and the timing of flowering and leaf fall in a Neotropical forest. In Reproductive ecology of tropical forest plants (K.S. Bawa \& M. Hadley, eds.). Man and Biosphere Series, UNESCO, Parthenon Publishing, Paris, p.49-61.

XIONG, S. \& NILSSON, C. 1997. Dynamics of litter accumulation and its effects on riparian vegetation: a review. Botanical Review 63:240-264. 